\title{
研究論文
}

ベンチスケール装置を用いた超電導磁気分離によるし尿処理

井原 一高 ${ }^{* 1, \dagger}$, 渡辺 恒雄 ${ }^{* 2}$

\section{Human Wastewater Treatment by Superconducting Magnetic Separation Using a Bench Scale System}

\author{
Ikko IHARA $^{* 1, \dagger}$ and Tsuneo WATANABE ${ }^{* 2}$
}

\begin{abstract}
Synopsis: A physico-chemical process combined with electrocoagulation using iron electrodes, high gradient magnetic separation and electrochemical oxidation was investigated for human wastewater treatment using a bench scale system. Magnetically-seeded suspended solids and phosphorus in human wastewater were removed effectively at a flow rate of $100 \mathrm{~L} / \mathrm{h}$ applying magnetic separation using a magnetic filter at $10 \mathrm{~T}$. The electrochemical oxidation process reduced ammonium nitrogen $\left(\mathrm{NH}_{4}-\mathrm{N}\right)$ and chemical oxygen demand (COD) in effluent from the magnetic filter at a flow rate of $15 \mathrm{~L} / \mathrm{h}$. The results indicate that this physico-chemical process is effective treating human wastewater.
\end{abstract}

Keywords: electrochemical oxidation, electrocoagulation, high-gradient magnetic separation, human wastewater (Some figures in this article may appear in colour only in the electronic version)

\section{1.はじめに}

下水道システムをはじめとする集中型廃水処理において, 有機污濁物質の浄化を担う主たるプロセスは活性污泥法や 嫌気性消化の生物処理である。下水道によって集水し，終 末処理場で集中的に処理を行う方法は，日本において河川， 湖沼そして海域といった閉鎖系水域の保全に大きく寄与し てきた。しかし，都市部ではなく農村部のような，排出源 密度の低い地域における下水道の敷設には経済上の制約が ある。

下水道や農村集落排水施設が普及していない地域におい て，し尿処理施設が必要になる。環境省は 2002 年に廃棄 物の処理および清掃に関する法律施行令等の一部を改正し,

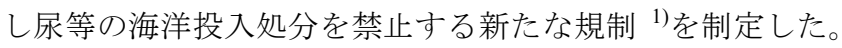
し尿処理施設での対象廃水は，有機污濁物質だけではなく 窒素そしてリン濃度が高いことが一般的である。一部のし 尿処理施設では, 処理水の水質改善のため, 生物的な硝化

Received December 18, 2019

${ }^{* 1}$ 神戸大学 大学院農学研究科

T657-8501 兵庫県神戸市灘区六甲台町 1-1

Department of Agricultural and Socio-Economics, Kobe

University, 1-1 Nada-ku, Kobe, Hyogo 657-8501, Japan

${ }^{*} 2$ 首都大学東京

厂192-0397 東京都八王子市南大沢 1-1

Tokyo Metropolitan University, 1-1 Minamiosawa, Hachioji,

Tokyo 192-0397, Japan

† E-mail: ihara@port.kobe-u.ac.jp

DOI: $10.2221 /$ jcsj. 55.195
脱窒プロセスと活性炭等による高度処理を組み合わせた方 法が採用されている。生物処理の弱点を補うためには, 富 栄養化の原因物質である窒素・リンの効率的な処理や，着 色成分の除去が可能なシステムが必要である。さらに, 人 口増加地域におけるし尿処理施設の課題として, 施設敷地 面積の制約から水処理システムの小型化が挙げられる。

冷凍機冷却技術の発達により超電導マグネットの性能が 向上し, 強磁場の応用として高勾配磁気分離による廃水処

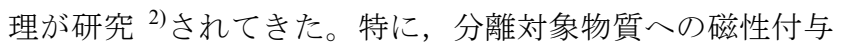
法である磁気シーディング技術の発展により, 様々な廃水

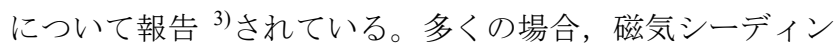
グの際に強磁性物質であるマグネタイトを使用している。 一方，マグネタイトを使用しない磁気シーディング法とし て電気化学凝集法 ${ }^{4,5)}$ が報告されている。本研究では, 物 理化学的な処理手法として電気化学凝集, 高勾配磁気分離 そして電気化学的酸化処理を組み合わせた方法をし尿処理 に適用した。超電導マグネットを含むベンチスケール装置 を用いて, 有機污濁物質だけではなくリンや窒素の除去性 能を明らかにすることを目的とした。

\section{2. 実験材料および方法}

\section{1 対象水}

廃水処理試験は, 地方自治体のし尿処理施設敷地内で実 施した。し尿および浄化槽污泥の混合水に対し, 固液分離 された廃水を実験対象水とした。 


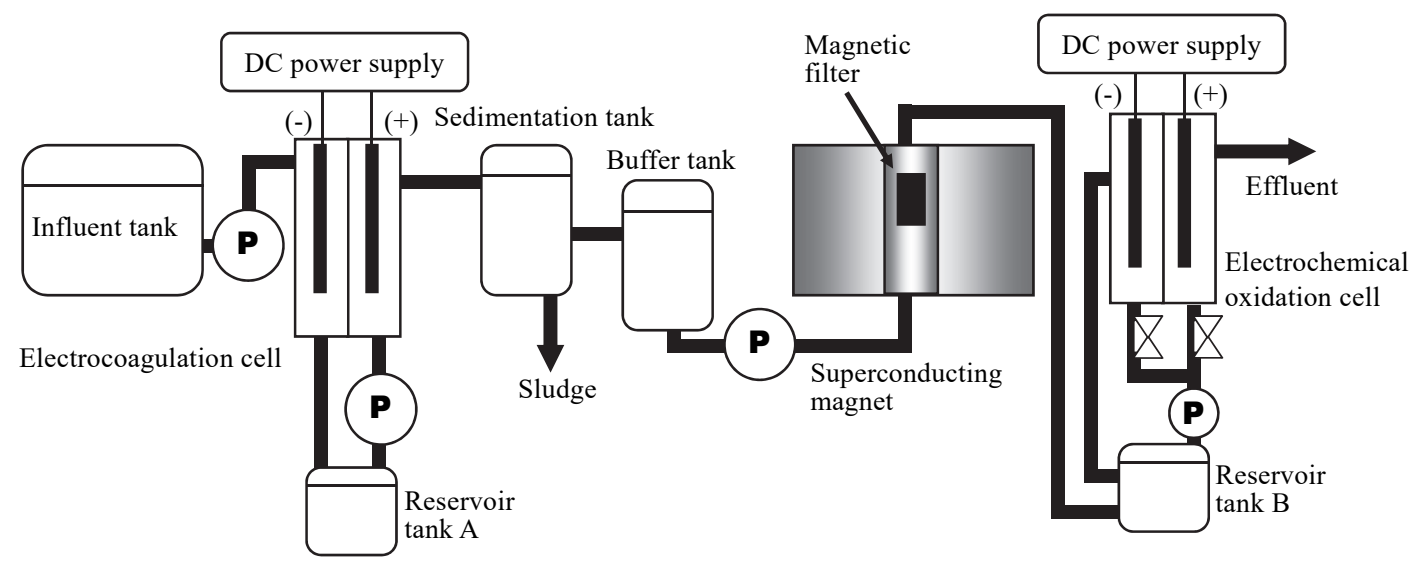

Fig. 1 Schematic diagram of a human wastewater treatment system

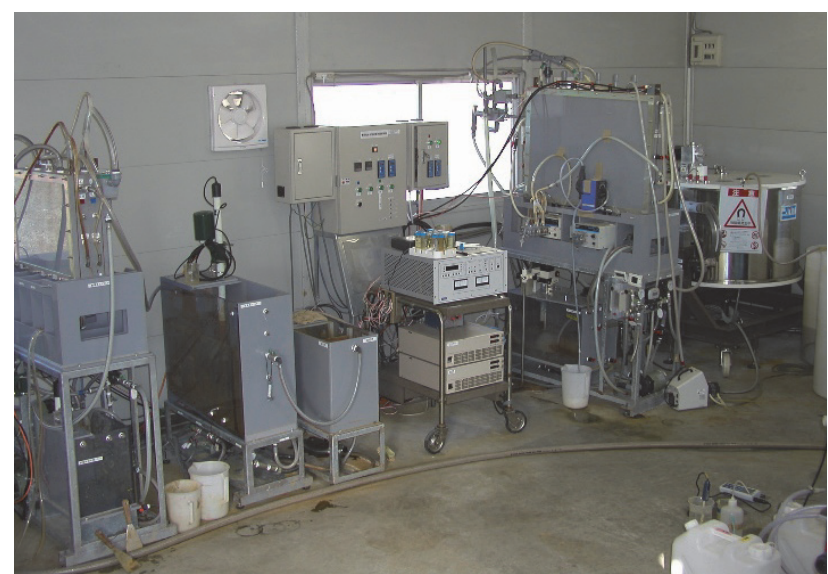

Fig. 2 Photo of a human wastewater treatment system.

\section{2 し尿処理システム}

処理システムの概略を Fig. 1 に, 外観写真を Fig. 2 に示 した。最初に実験対象水に対し, 磁気シーディングを目的 として電気化学凝集を行った。陽極, 陰極共に鉄プレート $(580 \times 350 \mathrm{~mm})$ を使用し，電極間隔は $100 \mathrm{~mm}$ とした。 電極間にはアニオン交換膜を設置し, 水, 䀣濁物質, 溶存 有機物そしてカチオンを殆ど通さないようにした。陽極側 および陰極側共に，容積は $10 \mathrm{~L}$ である。陰極側だけでは なく陽極側にも一定流量で溶液を移送させるためにリザー バタンク A $(20$ L $)$ を設置した。まず陰極側に通水しリ ザーバタンク A に排出させた後, ポンプで陽極側に 100 $\mathrm{L} / \mathrm{h}$ の流量で通水した。直流電源を用いて電流を $10 \mathrm{~A} に$ 設定し, 溶液に鉄成分を溶出させた。陽極側から排出され た溶液は沈降槽（容積 $80 \mathrm{~L}$ ，水面積 $1900 \mathrm{~cm}^{2}$ ) および調 整槽（60 L）に移送し，懸濁成分を沈殿させた。

続いて凝集粒子の除去を目的として, 磁気フィルタを用 いた高勾配磁気分離システムによる磁気分離を行った。ア クリル製キャニスタ（内径 $90 \mathrm{~mm}$ ）を用いて磁気フィル タを装着した超電導マグネット（JASTEC，JMTD$10 \mathrm{~T} 100 \mathrm{SS})$ に, 調整槽の上澄夕液を通過させた。磁気
フィルタとして，シームレスメッシュ（SUS430, 線径 0.1 $\mathrm{mm}$ ）を同心円状に密に巻いたもの（直径 $90 \mathrm{~mm}$, 高さ 60 $\mathrm{mm}$ ）を 2 セット使用した。磁気フィルタを通過する溶液 の流量は $1.7 \mathrm{~L} / \mathrm{min}$ に設定した。

さらに残留成分に対して，特にアンモニア性窒素を低減 させるために電気化学酸化処理を行った。陽極は, 次亜塩 素酸を効率的に生成させるために塩素発生用 DSA (Dimensionally stable anode) ${ }^{6)}$ を選択し，陰極は鉄とした。 陽極，陰極共に有効電極寸法は $850 \mathrm{~mm} \times 590 \mathrm{~mm}$ であり， 電極形状はメッシュである。両極間にカチオン交換膜を設 置し，電極間を $30 \mathrm{~mm}$ に配置した。陽極側容積は $15 \mathrm{~L}$, 陰極側容積は $35 \mathrm{~L}$ である。電流は $80 \mathrm{~A}$ の定電流に設定し, 処理速度は $15 \mathrm{~L} / \mathrm{h}$ とした。磁気分離によって処理された 廃水はリザーバタンク B $(60$ L $)$ に連続的に通水した。酸 化反応は陽極側で進行することから, ポンプで陽極側の滞 留時間を $1 \mathrm{~h}$ になるように注水し, 陽極側からの流出液を 処理水とした。また，陰極側にも $3 \mathrm{~L} / \mathrm{min}$ の流量で同時に 通水し, 排出された水はリザーバタンク $\mathrm{B}$ に返送させた。

\section{3 分析方法}

固形物の指標として懸濁物質（Suspended Solids, SS）を 測定した。ガラス䋊維ろ紙（Whatman 934-AH）でサンプ ルをろ過し， $103-105^{\circ} \mathrm{C}$ で水分を蒸発させ乾燥重量を測定 した。

富栄養化物質として全リン（Total Phosphorus, TP）とア

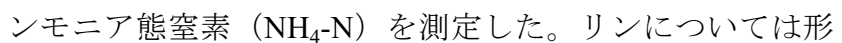
態による影響を評価するため，懸濁態リン（Suspended Phosphorus, SP) と溶存態リン (Dissolved Phosphorus, DP) についても測定した。0.45 $\mu \mathrm{m}$ のメンブランフィルタを用 いてサンプルを濾過し，濾過サンプルの TP 濃度を DP 濃 度とした。SP は廃水中に含まれる TP 濃度と DP 濃度との 差分から求めた。 TP, SP および DP はペルオキソ二硫酸 カリウムを用いて分解し, アスコルビン酸法によって分析 した。 $\mathrm{NH}_{4}-\mathrm{N}$ はサルチル酸法によって分析した。 


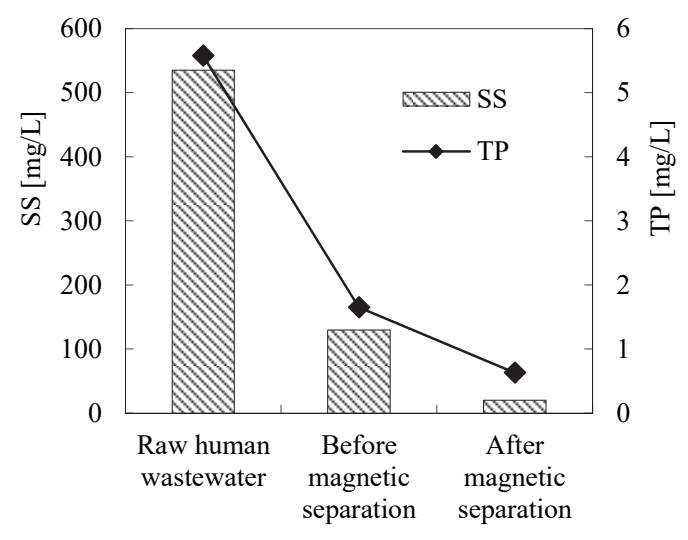

Fig. 3 Magnetic separation of SS and TP in human wastewater at $10 \mathrm{~T}$.

有機污濁物質濃度の指標として, 化学的酸素要求量 (Chemical Oxygen Demand, COD) を重クロム酸法によって 分析した。

\section{3. 結果および考察}

\section{1 電気化学凝集および磁気分離による懸濁物質およ びリンの除去}

超電導マグネットの印可磁場を $10 \mathrm{~T}$ に設定し, 電気化学 凝集および磁気分離による SS と TP の濃度変化を Fig. 3 に 示す。鉄電極を用いて電気化学凝集を行うと陽極の鉄が析 出し, 溶液中に鉄水酸化物 $\mathrm{Fe}(\mathrm{OH})_{2}$ や $\mathrm{Fe}(\mathrm{OH})_{3}$ が生成され る。これらについて 2 つの反応 ${ }^{7)}$ が提案されている。 反応 1 :

$$
\begin{array}{ll}
\text { 陽極 : } & \mathrm{Fe}_{(\mathrm{s})} \rightarrow \mathrm{Fe}^{2+}{ }_{(\mathrm{aq})}+2 \mathrm{e}^{-} \\
& \mathrm{Fe}^{2+}{ }_{(\mathrm{aq})}+2 \mathrm{OH}^{-}{ }_{(\mathrm{aq})} \rightarrow \mathrm{Fe}(\mathrm{OH})_{2(\mathrm{~s})} \\
\text { 陰極 : } & 2 \mathrm{H}_{2} \mathrm{O}_{(\mathrm{l})}+2 \mathrm{e}^{-} \rightarrow 2 \mathrm{OH}^{-}{ }_{(\mathrm{aq})}+\mathrm{H}_{2(\mathrm{~g})} \\
\text { 全体 : } & \mathrm{Fe}_{(\mathrm{s})}+2 \mathrm{H}_{2} \mathrm{O}_{(\mathrm{l})} \rightarrow \mathrm{Fe}(\mathrm{OH})_{2(\mathrm{~s})}+\mathrm{H}_{2(\mathrm{~g})}
\end{array}
$$

反応 2 :

$$
\begin{array}{ll}
\text { 陽極 : } & 4 \mathrm{Fe}_{(\mathrm{s})} \rightarrow 4 \mathrm{Fe}^{2+}{ }_{(\mathrm{aq})}+8 \mathrm{e}^{-} \\
& 4 \mathrm{Fe}^{2+}{ }_{(\mathrm{aq})}+10 \mathrm{H}_{2} \mathrm{O}+\mathrm{O}_{2(\mathrm{~g})} \rightarrow 4 \mathrm{Fe}(\mathrm{OH})_{3(\mathrm{~s})}+8 \mathrm{H}^{+} \\
& \text {(6) } \\
\text { 陰極 : } & 8 \mathrm{H}^{+}{ }_{(\mathrm{aq})}+8 \mathrm{e}^{-} \rightarrow 4 \mathrm{H}_{2(\mathrm{~g})} \\
\text { 全体 : } & 4 \mathrm{Fe}_{(\mathrm{s})}+10 \mathrm{H}_{2} \mathrm{O}_{(\mathrm{l})}+\mathrm{O}_{2(\mathrm{~g})} \rightarrow 4 \mathrm{Fe}(\mathrm{OH})_{3(\mathrm{~s})}+4 \mathrm{H}_{2(\mathrm{~g})}
\end{array}
$$
生成された金属水酸化物は常磁性物質と考えられ，鉄電極 を用いた電気化学凝集は磁気シーディング法として利用で きることが報告 ${ }^{4,5)}$ されている。今回供試した廃水には 535 $\mathrm{mg} / \mathrm{L}$ の $\mathrm{SS}$ と $5.6 \mathrm{mg} / \mathrm{L}$ の TP が含まれていた。電気化学凝 集後の沈降分離によって, 大部分の SS および TP は除去さ れ，それぞれ $130 \mathrm{mg} / \mathrm{L}, 1.7 \mathrm{mg} / \mathrm{L}$ となった。沈降分離され なかった SS, TP を含む上澄みに対して，磁気フィルタを 装着した超電導マグネットによる高勾配磁気分離を適用し た。電気化学凝集によって磁性を付与された懸濁物質はマ グネタイトのような強磁性ではないが，磁気分離後の濃度 は, SS が $36 \mathrm{mg} / \mathrm{L}, \mathrm{TP}$ が $0.6 \mathrm{mg} / \mathrm{L}$ 一と低減された。この ことから $100 \mathrm{~L} / \mathrm{h}$ の実用的な流量での連続分離が可能であ

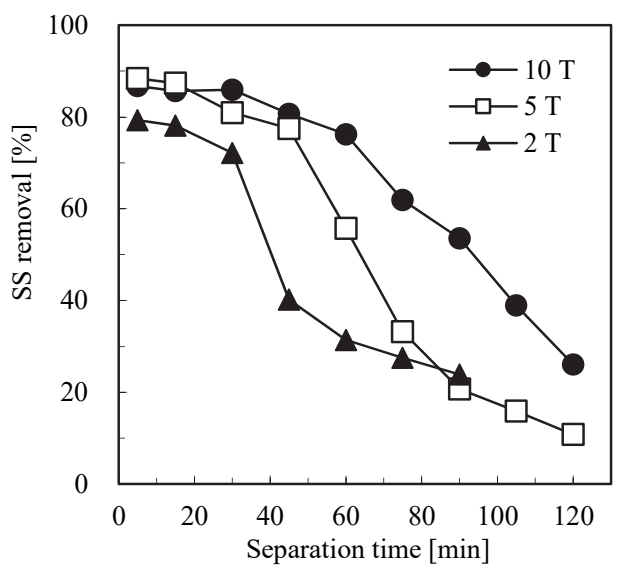

Fig. 4 Effect of magnetic field on magnetic separation of $\mathrm{SS}$ in human wastewater.

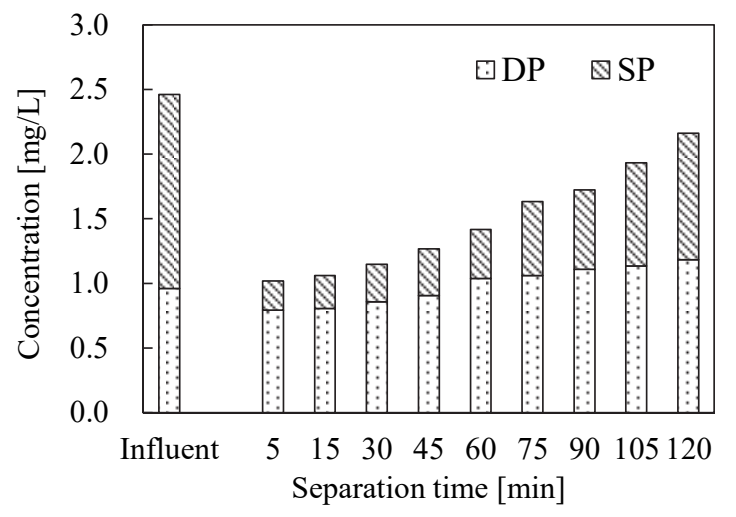

Fig. 5 Magnetic separation of SP and DP in human wastewater at $10 \mathrm{~T}$.

ることが示された。

電気化学凝集後に沈殿槽で重力沈降させた溶液に対し磁 気分離を行い, SS 除去に対する磁場強度の影響を Fig. 4 に 示す。いずれの場合も, 分離時間の経過とともに, 除去率 は低下する傾向にあった。その理由として, 磁気フィルタ において対象粒子の捕捉に必要な磁場勾配があるステンレ ス細線の近傍が捕捉された凝集物によって占有されたこと が考えられる。磁場強度を下げると除去率は低下し, その 影響は顕著であった。磁場強度が $2 \mathrm{~T}$ の場合, 分離時間が 30 分を超えると除去率は急激に低下した。

富栄養化物質であるリンは, 廃水中ではリン酸イオンと して存在していることが多い。リン酸イオンは金属イオン と容易に結合する性質を利用し，リン除去一応用できる。 鉄イオンの場合では, 次式の反応 ${ }^{8)}$ が挙げられる。

$$
\begin{aligned}
& 3 \mathrm{Fe}^{2+}+2 \mathrm{PO}_{4}{ }^{3-} \rightarrow \mathrm{Fe}_{3}\left(\mathrm{PO}_{4}\right)_{2} \\
& \mathrm{Fe}^{3+}+\mathrm{PO}_{4}{ }^{3-} \rightarrow \mathrm{FePO}_{4}
\end{aligned}
$$

鉄電極を用いた電気化学凝集および沈殿後の溶液に対し, $10 \mathrm{~T}, 100 \mathrm{~L} / \mathrm{h}$ の条件で磁気分離を行い, 磁気フィルタ流出 液の SP および DP の濃度変化を Fig. 5 に示した。鉄電極を 用いた電気化学凝集によって, し尿廃水に含有する溶存態 リンの一部はリン酸鉄として眯濁され，さらに一部が沈殿 


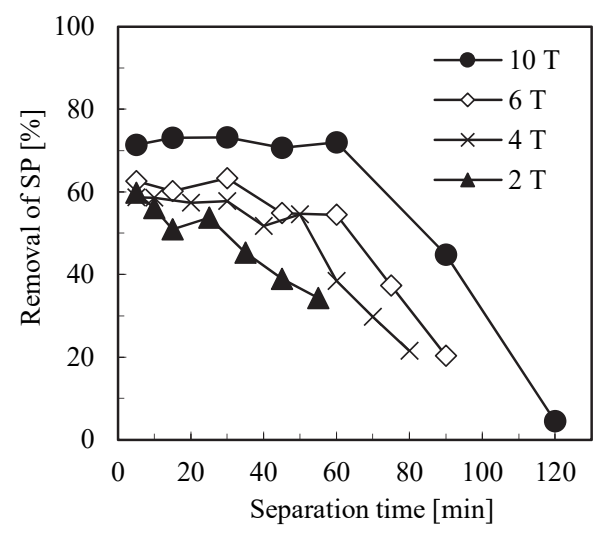

Fig. 6 Effect of magnetic field on magnetic separation of SP.

槽で重力分離されたと考えられる。磁気フィルタ流入水を 分析したところ, SP と DP が約半分ずつ含まれていた。 Fig. 5 に示すとおり, SP と DP はいずれも流出濃度は時間 経過とともに増加したが，磁気フィルタで分離されたのは 主として SP であった。DP は殆ど低減されなかった。リン 酸鉄をはじめとする眯濁されたリンは常磁性と考えられ, 磁気力で磁気フィルタに捕捉された。対照的に電気化学凝 集後においても, DP は磁性が付与されていないことから 磁気分離による除去効果は殆ど得られなかった。従って, 高勾配磁気分離は鉄電極を用いた電気化学凝集によって磁 気シーディングされたリンの除去に有効であることが示さ れた。SP の磁気分離における磁場強度の影響を Fig. 6 に示 す。磁場強度が $10 \mathrm{~T}$ の場合に最も除去率が高く, 磁場強度 の低いほど除去率は低下する傾向にあった。また，いずれ の磁場強度においても分離時間の経過に伴って, DP の除 去率は低下した。これらの傾向は Fig. 4 で示した SS の場合 と類似していた。リン除去率のさらなる向上のためには, 磁場強度を増加させるだけではなく, 電気化学凝集によっ て溶存態のリンをより多くに懸濁態に変化させることが必 要である。鉄電極の表面状態について $\mathrm{pH}$ と電位の関係を 図示した Pourbaix diagram ${ }^{9}$ によよると, 溶液をアルカリ領域 にすることによって, 磁気シーディングに関係する水酸化 鉄の鉄化合物がより多く生成する可能性がある。

\section{2 磁気分離の後処理としての電気化学的酸化処理}

前述のとおり, 電気化学凝集および磁気分離は, 磁気 シーディングされた成分に対しては除去効果が高いが，磁 気シーディングが困難な COD や $\mathrm{NH}_{4}-\mathrm{N}$ といった成分は低 減効果が低く, 後処理が必要になる。そこで, 電気化学凝 集および磁気分離後に電気化学酸化処理を実施した。SS, TP, COD, $\mathrm{NH}_{4}-\mathrm{N}$ の処理結果を Table 1 に示す。また処理 液の外観を Fig. 7 に示す。

電気化学凝集および高勾配磁気分離によって SS および TP は大幅に低減されたが, COD および $\mathrm{NH}_{4}-\mathrm{N}$ はそれぞれ $230 \mathrm{mg} / \mathrm{L} ， 445 \mathrm{mg} / \mathrm{L}$ であった。COD が低減された理由とし て, 電気化学凝集によって生成された鉄水酸化物に廃水中
Table 1 Magnetic separation and electrochemical oxidation of human wastewater.

\begin{tabular}{ccccc}
\hline$[\mathrm{mg} / \mathrm{L}]$ & $\mathrm{SS}$ & $\mathrm{TP}$ & $\mathrm{NH}_{4}-\mathrm{N}$ & $\mathrm{COD}_{\mathrm{Cr}}$ \\
\hline $\begin{array}{c}\text { Raw human } \\
\text { wastewater }\end{array}$ & 588 & 4.7 & 465 & 760 \\
$\begin{array}{c}\text { After magnetic } \\
\text { separation }\end{array}$ & 53 & 1.6 & 445 & 230 \\
$\begin{array}{c}\text { After electrochemical } \\
\text { treatment }\end{array}$ & - & - & 221 & 180 \\
\hline
\end{tabular}

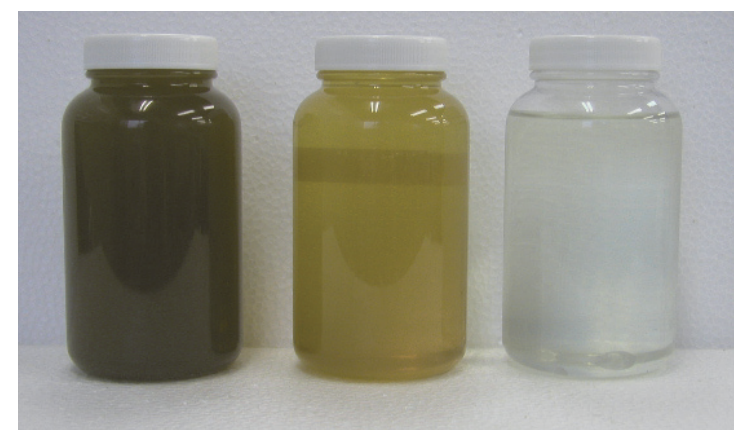

Fig. 7 Photo of raw human wastewater, effluent from magnetic separation and effluent from electrochemical oxidation cell.

の污濁成分が吸着し，磁性シーディングされたことが考え られる。鉄電極を用いた電気化学凝集は, 有機系污濁廃水 処理の適用事例が報告 ${ }^{10,11)}$ されている。一方, $\mathrm{NH}_{4}-\mathrm{N}$ は磁 気分離では殆ど低減されなかった。

Table 1 に示寸とおり, 磁気分離後の電気化学酸化処理に よって, COD は $180 \mathrm{mg} / \mathrm{L} に, \mathrm{NH}_{4}-\mathrm{N}$ は $221 \mathrm{mg} / \mathrm{L}$ にまで低 減された。廃水中に塩化物イオンが含まれる場合, アノー ド近傍で進行する直接酸化反応 ${ }^{12)}$ よりも, 主として電極間 バルクで進行する間接酸化反応 ${ }^{13)}$ によって, 電気化学的に 生成された次亜塩素酸が酸化剂として作用する。

$$
\begin{aligned}
& 2 \mathrm{Cl}^{-} \rightarrow \mathrm{Cl}_{2}+2 \mathrm{e}^{-} \\
& \mathrm{Cl}_{2}+\mathrm{H}_{2} \mathrm{O} \Leftrightarrow \mathrm{HClO}+\mathrm{Cl}^{-}+\mathrm{H}^{+} \\
& \mathrm{HClO} \Leftrightarrow \mathrm{ClO}^{-}+\mathrm{H}^{+}
\end{aligned}
$$

電気化学反応によって生成された次亜塩素酸は有機物に対 する酸化剂 ${ }^{14)}$ としても作用する。Table 1 に示すように $\mathrm{COD}$ は $230 \mathrm{mg} / \mathrm{L}$ から $180 \mathrm{mg} / \mathrm{L}$ 一と約 $50 \mathrm{mg} / \mathrm{L}$ 低減され た。対象サンプル中に塩化物イオンが多量に含有し, 使用 した DSA は高効率に塩素生成が可能であることから, 主 たる酸化剤として次亜塩素酸が対象水中の有機物に対して も作用したと考えられる。

次覀塩素酸は有機化合物の酸化分解だけではなく, アン モニア性窒素の処理 ${ }^{13)}$ 可能である。この反応は不連続点 塩素処理 (break point chlorination) ${ }^{15)}$ として上水処理で広く 利用されている。生成された次亜塩素酸は, $\mathrm{NH}_{4}{ }^{+}$と反応 し, 最終的に $\mathrm{N}_{2}$ への変換が可能である。

$$
\begin{aligned}
& \mathrm{NH}_{4}+\mathrm{HClO} \Leftrightarrow \mathrm{NH}_{2} \mathrm{Cl}+\mathrm{H}_{2} \mathrm{O}+\mathrm{H}^{+} \\
& \mathrm{NH}_{2} \mathrm{Cl}+\mathrm{HClO} \Leftrightarrow \mathrm{NHCl}_{2}+\mathrm{H}_{2} \mathrm{O}
\end{aligned}
$$




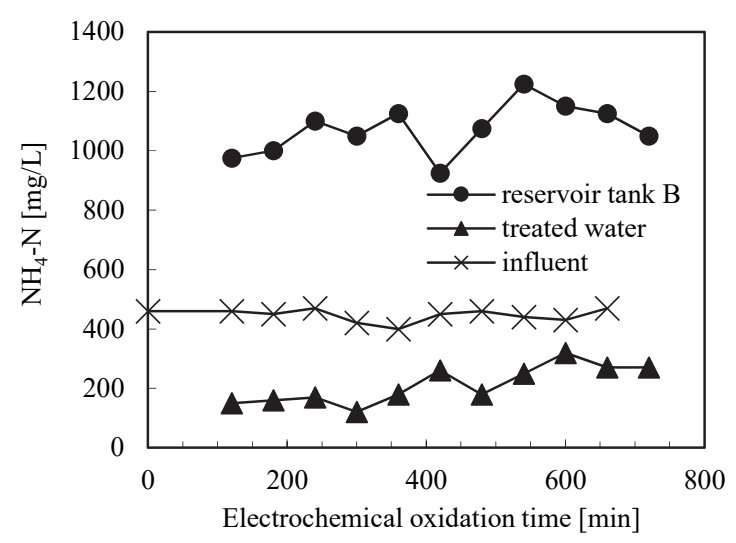

Fig. 8 Continuous treatment of $\mathrm{NH}_{4}-\mathrm{N}$ by electrochemical oxidation after magnetic separation.

$$
\begin{aligned}
& 0.5 \mathrm{NH}_{2} \mathrm{Cl}+0.5 \mathrm{H}_{2} \mathrm{O} \Leftrightarrow \mathrm{NOH}+\mathrm{H}^{+}+\mathrm{Cl}^{-} \\
& \mathrm{NHCl}_{2}+\mathrm{NOH} \Leftrightarrow \mathrm{N}_{2}+\mathrm{HClO}+\mathrm{H}^{+}+\mathrm{Cl}^{-}
\end{aligned}
$$

溶液に含まれる塩化物イオンから電気化学的に次亜塩素酸 が生成され, $\mathrm{NH}_{4}^{+}$と反応したためと考えられる。一連の反 応では, 生物的窒素除去である硝化脱窒と異なり炭素源を 必要としない。

電気化学酸化反応による連続処理における $\mathrm{NH}_{4}-\mathrm{N}$ の濃度 変化を Fig. 8 に示す。流入水中の $\mathrm{NH}_{4}-\mathrm{N}$ 濃度は 400-470 $\mathrm{mg} / \mathrm{L}$ に対し, 処理水は 150-270 mg/L の範囲で推移した。 また，電極間電圧は 3.8-7.0 V であった。(11)-(13)式に示す 反応によって生成した次亜塩素酸は陽極側で生成し，アン モニウムイオンとの反応が進行したと考えられる。電極間 にカチオン交換膜を設置したことによって, リザーバタン ク $\mathrm{B}$ における $\mathrm{NH}_{4}-\mathrm{N}$ の濃度は，流入水よりも高い傾向を 示した。アンモニウムイオンはカチオン交換膜を通過して 陽極側から陰極側へ移動し, 濃縮された。濃縮されたアン モニウムイオンは再び陽極側へ移送された。高濃度のアン モニウムイオンが電解セルの陽極側に注入されたことに よって，反応向上に寄与したと考えられる。

アンモニア性窒素および COD いずれに対しても，電気 化学反応によって生成された次亜塩素酸が分解反応に寄与 したと考えられる。一般に, 次亜塩素酸の酸化力は $\mathrm{pH}$ の 影響を大きく受ける。電気化学酸化反応によって $\mathrm{pH}$ は変 動することから，注意が必要である。対象溶液に十分な塩 化物イオンが含まれる場合, 電気化学反応によって生成さ れる次亜塩素酸は, 流れた電気量に比例する。すなわち, 対象水当たりの投入電気量を増加させることによって，更 なる水質の改善は可能であると考えられる。

\section{4. おわりに}

し尿廃水を対象として，鉄電極を用いた電気化学凝集， 超電導マグネットを用いた高勾配磁気分離そして電気化学 酸化を組み合わせた物理化学的廃水処理を適用し, ベンチ スケール装置を用いて有効性を検証した。鉄電極を用いた
電気化学凝集による磁気シーディングは，10 T, $100 \mathrm{~L} / \mathrm{h} の$ 流量による磁気分離によって懸濁物質やリンの除去に有効 であった。従来, マグネタイトといった強磁性物質を用い なくても，実用的な流量で磁気分離が可能であることを示 した。電気化学凝集および磁気分離処理では低減効果が低 かった COD や $\mathrm{NH}_{4}-\mathrm{N}$ に対しては, 電気化学酸化処理が有 効であった。提案した物理化学的手法によるし尿処理浄化 は, 生物学的プロセスを使用しないことから, 処理システ ムの小型化, 生成污泥の減容そして処理時間の短縮に寄与 すると考えられる。

\section{参 考 文 献}

1) 環境省：「廃棄物の処理及び清掃に関する法律施行令等の一 部を改正する政令について」, 環境省報道発表資料, http://www.env.go.jp/press/3076.html（参照 2019-11-30）

2) T. Ohara: "From basic research to industrial application of superconducting magnets in magnetic separation," TEION KOGAKU 37 (2002) 303-314 (in Japanese)

小原健司：「磁気分離研究開発の経緯 超電導マグネット応用 の視点から」, 低温工学, 37 303-314 (2002)

3) S. Takeda: "Magnetically seeding process," TEION KOGAKU 37 (2002) 315-320 (in Japanese)

武田真一:「磁気分離のための担磁法」, 低温工学 37 (2002) 315-320

4) C. Tsouris, D.W. DePaoli, J.T. Shor, M.Z.C. Hu and T.Y. Ying: "Electrocoagulation for magnetic seeding of colloidal particles," Colloids and Surfaces A: 177 (2001) 223-233

5) I. Ihara, K. Toyoda, N. Beneragama and K. Umetsu: "Magnetic separation of antibiotics by electrochemical magnetic seeding," J. Phys.: Conf. Ser. 156 (2009) 012034

6) S. Trasatti: "Electrocatalysis: understanding the success of DSA," Electrochimica Acta 45 (2000) 2377-2385

7) O. Larue, E. Vorobiev, C. Vu and B. Durand: "Electrocoagulation and coagulation by iron of latex particles in aqueous suspensions," Separation and Purification Technology 31 (2003) 177-192

8) H. Nakajima and Y. Sakakibara: "Fundamental study on a novel phosphate removal and recovery method using iron electrodes," Environmental Engineering Research 36 (1999) 129-136 (in Japanese)

中島広樹，榊原 豊：「鉄電極を用いた新しいリン除去・回 収法に関する基礎的研究」, 環境工学研究論文集 36 (1999) 129-136

9) W.G. Cook and R.P. Olive: "Pourbaix diagrams for the iron-water system extended to high-subcritical and low-supercritical conditions," Corrosion Science 55 (2012) 326-331

10) R. Katal and H. Pahlavanzadeh: "Influence of different combinations of aluminum and iron electrode on electrocoagulation efficiency: Application to the treatment of paper mill wastewater," Desalination 265 (2011) 199-205

11) K. Eryuruk, U.T. Un and U.B. Ogutveren: "Electrochemical treatment of wastewaters from poultry slaughtering and processing by using iron electrodes," J. of Cleaner Production 172 (2018) 1089-1095 
12) C. Comninellis: "Electrocatalysis in the electrochemical conversion/combustion of organic pollutants for waste water treatment," Electrochemical Acta 39 (1994) 1857-1862

13) L.C. Chiang, J.E. Chang and T.C. Wen: "Indirect oxidation effect in electrochemical oxidation treatment of landfill leachate," Water Research 29 (1993) 671-678

14) C. Comninellis and A. Nerini: "Anodic oxidation of phenol in the presence of $\mathrm{NaCl}$ for wastewater treatment," J. of Applied Electrochemistry 25 (1995) 23-28

15) G.C. White: "The handbook of Chlorination (2nd ed.)" Van Nostrand Reinhold, New York (1985) 172-175
井 原 - 高 1972 年 1 月生。1995 年筑波大学生物資源学 類卒業。2001 年同大学院農学研究科博士課程（農林工学専攻） 修了。2001 年東京都立大学工学研究科学術研究員。超電導マグ ネットを用いた水質浄化研究に従事。2012 年神戸大学農学研究 科准教授。畜産バイオマスの変換に関する研究に従事。低温工 学・超電導学会, 農業施設学会, 日本磁気科学会会員。博士（農 学)。

渡 辺 恒 雄 1944 年 2 月生。19688 年京都大学大学院工 学研究科博士前期課程（電気工学専攻）修了。1968 年（財）電 力中央研究所勤務。ガス絶縁設計, 電気集塵装置高度化に従事。 1991 年東京都立大学工学部教授。主に電気と磁場を利用した環 境保全技術開発に関する研究に従事。低温工学・超電導学会, 電 気学会会員。工学博士。 